\title{
Assessing the effects of trade openness on sustainable development: evidence from India
}

\author{
Mehraj Ahmad Sheikh ${ }^{1 *}$ (D, Mushtaq Ahmad Malik ${ }^{2}$ and Rana Zehra Masood ${ }^{1}$
}

\author{
* Correspondence: mehrajzhdc@ \\ gmail.com \\ 'Department of Commerce, Aligarh \\ Muslim University, Aligarh, India \\ Full list of author information is \\ available at the end of the article
}

\begin{abstract}
Over the years, world market is integrating at much faster pace through increasing trade openness. Not being an unmixed blessing, consistent efforts have been made to examine impact of trade openness on economic, environmental and social welfare. This study is an attempt to empirically examine the implications of trade openness on sustainable development in India since liberalization policy 1991. We used the Autoregressive Distributed Lag (ARDL) model to test the relationship between sustainable development and trade openness along with other control variables that are supposed to affect sustainable development. The results established supports the opinion of environmentalists. The empirical results are contrary to the conventionally held belief, indicating that trade shares a negative correlation with green GDP growth and positive correlation with gap between conventional GDP and green GDP. These findings support the arguments that trade openness tend to be both distorting and detrimental to the future generations.
\end{abstract}

Keywords: Trade openness, Genuine savings, Sustainable development, ARDL approach

\section{Introduction}

The increasing globalization has constantly changed the world. Over the past few decades, radical social economic and environmental moves have taken place. Because of reckless production and consumption, the natural capital of the world is under enormous pressure. The rapid liquidation of natural and social capital has led to daunting problems of global warming, ozone depletion, biodiversity loss, impoverishment and unequal distribution of wealth. These issues have placed the 'sustainable development' policy objective at the centre of the policy action. Indeed, sustainable development has largely penetrated into institutions, government, businesses, voluntary bodies and others. Among the wide range of policies, trade policy remains a focal point for both direct and indirect relations with sustainable development. Since it has potential to expand the economic space needed to create new job opportunities, efficient resource utilization and the generation of managerial and entrepreneurial skills required for economic growth and development. Trade as a catalyst is widely recognized as a powerful engine of sustainable development Balassa (1986). As former GATT Director-General Arthur Dunkel (reported by Weiss's (1992)) puts it, trade is not an end to

(c) The Author(s). 2020 Open Access This article is distributed under the terms of the Creative Commons Attribution 4.0 International License (http://creativecommons.org/licenses/by/4.0/), which permits unrestricted use, distribution, and reproduction in any medium, provided you give appropriate credit to the original author(s) and the source, provide a link to the Creative Commons license, and indicate if changes were made. 
environmentally sustainable economic development, but rather a powerful enabler or engine. In general, the WTO Doha Ministerial Declaration also firmly reaffirmed its commitment to the sustainability target. Not only sustainability being an explicit goal of trade policy, but there is a growing trend to use trade policy as a tool for promoting specific sustainability goals. Trade remains a contentious issue in any developmental discussion without a quick fix solution for its ability to affect either way the economy, culture and climate. We believe that this issue can be resolved by taking alternative welfare measures instead of simple GDP growth rates. One of the popular alternative, among others, is Genuine Savings (GS) to give a sense of whether an economy is on the path of sustainability. This study attempts to bridge this gap by empirically investigating the validity of various assertions by means of alternative development measures. If trade openness promotes sustainability, as proponents claim, then such improvement should be indicative of its impact on economic, social and environmental capital.

The rest of the article proceeds with section 2 reviews the empirical literature and section 3 discusses the construction of sustainability index, model specification, data and ARDL approach. Section 4 presents the analysis and interpretation of empirical results. Section 5 summarizes and presents the concluding remarks.

\section{Review of literature}

All three dimensions of sustainability (economic social and environmental) have been scrutinized intensively and enjoy a considerable volume of literature. The merits of trade have been debated by economists, environmentalists and social commentators for decades. Trade openness proponents see it as a sine qua non for growth in developing countries and therefore should comply with a positive global trade policy (Krueger, 1998 \& Were 2015). Trade openness has been stressed on a larger scale from mercantilism to classical theories. Much stronger emphasis on trade openness can be found within the framework of modern endogenousgrowth models, which directly linked growth and endogenously selected policy options such as outward oriented trade regimes Dowrick (1994). United Nations' World Economic Survey 1962, said that economic problems of low income countries cannot be tackled without raising their manufactured export Kaldor (1964). Commenting further, Mountford (1999) argued that trade contributes to the sorting of world economies into high and low growth countries and creates patterns of catch-up and/or overtaking. Empirically, trade helps in efficient resource reallocation (static gains) and ushers dynamic advantages in the form of an expanded market for domestically produced goods, changing attitudes and institutions, increased competition, higher investment flows, faster productivity growth, learning by doing, acquiring new knowledge and ideas, Lee (1995), Kraay (1999), Coe and Helpman (1995). Exposure to foreign externalities also enhances the performance of non-export sectors, accelerating overall economic growth (Romer (1986), Lucas (1988), Stokey (1988), Froning (2000) and Dollar (1992). Increasing competition by trade liberalization also decreases the losses of deadweight incurred by domestic monopolies and oligopolies, and thereby bringing additional gains, Krishna and Mitra (1998).

Rodrigues and Rodrik (1999) questioned the measurement of trade openness, despite these upbeat assessments by proponents. He was unable to find a clear cut relationship between trade and development, but such a relationship is contingent on a number of 
external and country specific factors. Furthermore, environmentalists harbour the legitimate fear that underneath this new wave of increasing economic integration lurks the all too familiar politics of economic growth that has contributed to the biosphere's destruction. Free trade opponents, who bring strong moral convictions to the debate, are convinced of the negative environmental and social impacts of trade openness. These journalistic arguments suggest that increased trade leads 'global pillage 'Brecher and Costello's (1994). High energy use for economic growth contributes significantly to environmental degradation, Dar and Asif (2018). Increasing trade may lead poorer countries to 'specialization trap 'by maintaining their dependence on primary exports Ropke (1994). Copeland and Taylor (1994) concluded that the increase in revenue generated by trade can lead to a rise in the rate of world pollution. Rosenberg (1994) argued that further liberalization would only increase the unsustainable level of exploitation of resources. These passionate debates, are prompting countries to reconsider their trade actions in response to fears of carban leakage, Bellmann et al. (2011). The bulk of existing studies have concentrated on how trade globalization affects social welfare programs, making the poor more vulnerable and helping the better-off, Rudra (2008). Dependency theorists see international trade as a type of neo-colonialism that breaks the democracy and social relationships, Amin (1990). Since openness is associated with periodic shocks, it puts vulnerable groups at great risk Desai and Rudra (2018). Developing countries with increased trade in manufactured goods show evidence of reduced social protection coverage for the poor as well as for the general population. Critics claim that trade liberalization decapitalizes poorer countries by intensifying inappropriate consumption and repatriation of resources by foreign companies, Bornschier and Chase-Dunn (1985). In addition, business groups and investors in newly liberalizing countries are pressing governments to lower taxes and squeeze workers 'bargaining power Rudra (2002).

While trade continues to grow at an unprecedented rate, the empirical debate is still unsettled due to the fact that economic growth achieved through open trade is recognized as a universal remedy for social and environmental issues. Since growth in terms of raising GDP, has failed to account for many important dimensions of sustainability. As Stiglitz et al. (2010) puts it, GDP though primarily measures market production, has often been equated with the measurement of economic well-being. It can be seriously misleading to conflate market production with economic well-being to show how welloff people are. It also misses out on several critically important issues like unorganized market, distribution of economic goods and pollution costs etc. also Costanza et al. (2009).

\section{Methodology}

This section presents the construction of composite sustainability indicator, model specification and ARDL approach of cointegration.

\section{Construction of composite sustainable index (CSI)}

The index of sustainable development is obtained by means of an analytical approach (see Tokos et al. 2012 for detailed explanation). By normalizing their corresponding 
benchmarks, a representative set of economic, environmental and social indicators is transformed into dimensionless sub-indices, given in Eqs. 1 and 2 below

$$
\begin{aligned}
& N I_{i t d}^{+}=\frac{N I_{i t d}}{B M_{i t d}} \\
& N I_{i t d}^{-}=\frac{B M_{i t d}}{N I_{i t d}}
\end{aligned}
$$

Where, $\mathrm{NI}_{\text {itd }}^{+}$is the normalized indicator i from a particular dimension $\mathrm{d}$ having a positive influence on sustainable development at time $t$ and $N I_{i t d}^{-}$is the normalized indicator i from a particular dimension d having a negative influence on sustainable development at time t. $B M_{i t d}$ is the benchmark (the average value of the top five performers from among 30 developing countries for the year 2015) of each indicator $i$ at respective time periods t. The next step involved is the aggregation of respective normalized indicators $\left(N I_{i t d}\right)$ to construct sub-indices pertaining to their dimension as defined by Eqs. (3), (4) and (5) respectively.

$$
\begin{aligned}
& S U S_{\text {ec }}=\sum_{i=1}^{n e c} N I_{i t d} \\
& S U S_{\text {en }}=\sum_{i=1}^{n e n} N I_{i t d} \\
& S U S_{\text {so }}=\sum_{i=1}^{n s o} N I_{i t d}
\end{aligned}
$$

Where,

SUSec, SUSen and SUSso represent the economic environmental and social sustainability respectively. $i=1,2,3,4$ represents the indicator in a particular sub-index. Finally, all the sub-indices representing different dimensions of sustainable development are combined into a composite sustainability indicator through Eq. (6)

$$
C S I_{t}=S U S_{\text {ect }}+S U S_{\text {ent }}+S U S_{\text {sot }}
$$

Where, CSI represents the composite sustainability indicator at time $t$.

\section{Model specification}

\section{Relationship between trade openness and green GDP}

We start by establishing a relationship between trade openness and green GDP through a simple cob-Douglas production function given below:

$$
G G D P_{t}=L a b_{t}+\mathrm{Cap}_{t}+\mathrm{TO}_{t}
$$

Where, GGDP $P_{t}$ represents the green GDP. $\mathrm{Lab}_{t}, \mathrm{Cap}_{t}$ and $\mathrm{TO}_{t}$ respectively indicate the amount of labor, capital and degree of openness of a country at a particular time $t$. In a specific form the equation can be written as follows:

$$
G G D P_{t}=\beta_{0}+\beta_{1} A D R_{t}+\beta_{2} G C F_{t}+\beta_{3} T O_{t}+v_{t}
$$

In this model, a particular class of green GDP known as Genuine Savings (GS) is incorporated into traditional economic growth model to analyze the influence of trade openness on overall sustainability. GS is defined as net savings adjusted for physical capital 
depreciation, human resource investment, and deterioration of the environment. GS determines the conditions for sustainability of a resource-dependent economy such as India on its ability to maintain a constant stream of consumption into the infinite future. Trade openness is measured by the ratio of trade intensity (export ratio plus GDP imports). ADR is the age-dependence ratio of the labor input. The ratio of dependency to the working population is known as the ratio of dependent class or non-working age population (15 and 64). The reasoning behind taking ADR is that it constrains growth by rising dependent population. The ratio of gross fixed capital formation (GCF) to real GDP at the US dollar 2010 reflects physical capital. All the variables are taken in their logarithmic form.

\section{GAP between GDP and green GDP}

Several studies have shown that there is an increasing gap between GDP and green GDP over time. The quality of life is improving, along with economic growth, but up to a certain threshold. From there any rise in economic growth will result in higher welfare costs, which will widen the gap (Max-Neef 1995 and Lawn 2003). As a developing country, India is striving to achieve higher economic growth. In such a situation, it is interesting to see if environmental degradation and other welfare costs offset or more than offset the rising economic activity. The 'GAP' model formulated by Talberth and Bohara (2006) is used to explore whether trade openness is widening the gap. In this model the role of trade openness along with social and environmental measures is analyzed in either widening or contracting the gap. Both social and environmental measures have a strong influence on green GDP. The general formulation of the model is given in Eq. 9 given below:

$$
G A P_{t}=\beta_{0}+\beta_{2} X_{t}+u_{t}
$$

Where, GAP is the difference between the conventional GDP and green GDP. $X$ is $1 * \mathrm{k}, \beta$ is $\mathrm{k}^{*} 1$ and $\mathrm{k}=3$ since we have three explanatory variables in $X$.

\section{ARDL approach to Cointegration}

In order to investigate the impact of underlying variables on green GDP, various econometric models can be resorted to. These include Engle Granger (1987). Maximum Likelihood-based Johansen (1988, 1991) and Johansen and Juselius (1990). However, these tests are severely sensitive to the stationarity property of the variables and length of the sample. To overcome these issues, we followed the autoregressive distributive lag (ARDL) approach developed by Pesaran and Shin (1999, 2001). ARDL approach, contrary to the other approaches performs better irrespective of order of integration of variables and determines both long as well as short run coefficients simultaneously. However, it underperforms when the data series are integrated of order I (2).

In consideration to this, we specify the ARDL ( $\mathrm{p} \mathrm{q}$ ) model 1 as fallows;

$$
\begin{aligned}
G G D P_{t}= & \alpha_{0}+\sum_{i=1}^{p} \alpha_{1} \Delta A D R_{t-i}+\sum_{\mathrm{i}=1}^{p} \alpha_{2} \Delta G C F_{t-i}+\sum_{i=1}^{p} \alpha_{3} \Delta T O_{\mathrm{t}-\mathrm{i}}+\rho_{2} \Delta A D R_{\mathrm{t}-1} \\
& +\rho_{3} \Delta G C F_{\mathrm{t}-1}+\rho_{4} T O_{\mathrm{t}-1}+v_{t}
\end{aligned}
$$

Where $\Delta$ is the first difference operator, $\mathrm{p}$ is the optimal lag length, $\alpha_{1}, \alpha_{2}$ and $\alpha_{3}$ are the short-run responses while as $\rho_{1}, \rho_{2}$ and $\rho_{3}$ represent the long-run responses of independent variables defined above. $v_{1}$ represents the regression error term. 
In order to check the robustness or our results, we also estimated the relationship between the trade openness and sustainability by using an alternative indicator called Composite Sustainability Index (CSI). The methodology of estimating CSI is given in appendix 1 . The specific form of model 2 is given by Eq. 4 .

$$
\begin{aligned}
C S I_{t}= & \beta_{0}+\sum_{i=1}^{p} \beta_{1} \Delta A D R_{t-i}+\sum_{\mathrm{i}=1}^{p} \beta_{2} \Delta G C F_{t-i}+\sum_{i=1}^{p} \beta_{3} \Delta T O_{\mathrm{t}-\mathrm{i}}+\gamma_{2} \Delta A D R_{\mathrm{t}-1} \\
& +\gamma_{3} \Delta G C F_{\mathrm{t}-1}+\gamma_{4} T O_{\mathrm{t}-1}+v_{t}
\end{aligned}
$$

Where, CSI is the Composite Sustainability Index, $\Delta$ is the first difference operator, $\mathrm{p}$ is the optimal lag length, $\alpha_{1}, \alpha_{2}$ and $\alpha_{3}$ are the short-run responses while as $\rho_{1}, \rho_{2}$ and $\rho_{3}$ represent the long-run responses of independent variables defined above. $v_{1}$ represents the regression error term.

The GAP model is estimated through the fallowing specification

$$
\begin{aligned}
G A P_{t}= & \lambda_{0}+\sum_{i=1}^{p} \lambda_{1} \Delta L P I_{t-i}+\sum_{\mathrm{i}=1}^{p} \lambda_{2} \Delta G I N I_{t-i}+\sum_{i=1}^{p} \lambda_{3} \Delta T O_{\mathrm{t}-\mathrm{i}}+\chi_{2} \Delta L P I_{\mathrm{t}-1} \\
& +\chi_{3} \Delta G I N I_{\mathrm{t}-1}+\chi_{4} T O_{\mathrm{t}-1}+v_{t}
\end{aligned}
$$

Where, LPI is the livestock production index, GINI represents the income inequality index, TO is the measure of trade openness and GAP is defined above. $\Delta$ is the first difference operator, $\mathrm{p}$ is the optimal lag length, $\lambda_{1}, \lambda_{2}$ and $\lambda_{3}$ are the short-run responses while as $\chi_{1}, \chi_{2}$ and $\chi_{3}$ represent the long-run responses of independent variables. $v_{1}$ represents the regression error term.

We rely on livestock production index (LPI) taken from World Bank as a control variable for measuring environmental degradation. LPI has a strong connection with environment, as increase in livestock production leads to overgrazing which in turn leads to deforestation, soil erosion, land degradation, riparian habitat loss and water pollution. The inclusion of other measures of environmental degradation would create a problem of collinearity because genuine savings are adjusted for almost all other such variables. However, livestock production is independent of any such adjustment. Further we incorporated distribution of income in our model which, Talberth and Bohara (2006) have not taken into consideration in their final model. We expect livestock production and income inequality to positively influence the gap. However no such assumption is made regarding effect of trade openness.

The data on all the variables except income inequality is taken from the World Development Indicators (WDI) 2018. For income inequality, we used estimated household income inequality data set computed by University of Texas Inequality Project. The data set has missing value for 2011 which was interpolated and was extended up to 2016 by extrapolation by authors themselves. Trade openness is taken same as in green GDP growth model. Due to non-availability of data beyond 2016 we restricted our self to that time span only.

\section{Empirical results and discussion}

This section presents the econometric estimation of the above mentioned ARDL model. Before application of ARDL model, the integration of all the variables must be checked. For that purpose, standard Augmented Dickey-Fuller test is employed. To determine the existence of long-run relationship or cointegration in Eq. (3), bounds test 
is used. Bounds test is used for [non] existence of any cointegrating relationship among variables using F-statistics. Null hypothesis is rejected [accepted] if F-statistic turns out to be greater [lower] than upper [lower] bounds critical values respectively. Values of F-statistic lying between the two bounds are considered as inconclusive. Cointegration testing is followed by selection of optimal lag length through various information criterion like AIC, BIC, $\mathrm{R}^{2}$ and $\mathrm{HQ}$.

\section{Stationarity test}

To begin with, the first exercise is to present the overview of the data itself. The statistical properties of the underlying variables are tested through application of standard Augmented Dickey-Fuller (ADF) test to all the variables both at levels as well as at first difference. The results are produced in Table 1.

In Table 1, column 3 portrays the $p$-values associated with the dynamic regressors are greater than any conventional level of significance. This rejects the null of variables having unit root. Therefore, it indicates that the variables are anything but I (0). However, ARDL severely underperform in a situation where variables are I (2). To validate the application of ARDL model, we applied ADF again at first difference of each variable. Column 4th and 5th of Table 1 present the T-values and their associated $p$-values respectively. The p-values significant at $1 \%$ significance level reject the notion of variables being I (2) and thereby validates the application of Bounds test. Bounds test confirms the presence or absence of long run relationship among variables. However before investigating such relationship, we present the summary statistics as given in Table 2.

Table 2 portrays the normality and stability of the underlying variables over the period of investigation. Jarque-Bera test static and its associated $p$-value indicate that the normality assumption is upheld. In a similar vein, the standard deviation of each variable is less that its mean values indicating the stable variation among them in the sample period. In what follows, we proceed with estimating the cointegrating relationship between the underlying variables. The presence or absence of equilibrium relationship is examined through bounds test. The results are produced in Table 3:

Table 1 unit root test

\begin{tabular}{|c|c|c|c|c|}
\hline \multirow[t]{2}{*}{ Variable } & \multicolumn{2}{|l|}{ At levels } & \multicolumn{2}{|c|}{ At 1st difference } \\
\hline & T value & $P$ value & T value & $P$ value \\
\hline LnTO & -1.665 & 0.437 & -5.56 & 0.001 \\
\hline LnGCF & 0.034 & 0.954 & -6.47 & 0.000 \\
\hline LnADR & -0.513 & 0.873 & -3.73 & 0.081 \\
\hline $\mathrm{CSI}$ & -0.483 & 0.880 & -8.08 & 0.000 \\
\hline LnGGDP & -0.989 & 0.743 & -5.01 & 0.000 \\
\hline LnGAP & 0.5147 & 0.98 & -7.59 & 0.000 \\
\hline LnLPI & 0.278 & 0.976 & -4.224 & 0.000 \\
\hline LnGINI & -1.081 & 0.379 & -4.012 & 0.001 \\
\hline
\end{tabular}

Source: author's own calculation

LnTO stands for log of trade openness, LnGGDP is the log of green GDP; LnADR is log of average dependency ratio; LnGCF log of gross capital formation and CSI stands for composite sustainability indicator 
Table 2 Descriptive Statistics

\begin{tabular}{lllllllll}
\hline & CSI & LnADR & LnGCF & LnGDP & LnTO & LnGAP & LnLPI & LnGINI \\
\hline Mean & 0.678179 & 4.103392 & 26.50785 & 25.59645 & 3.194964 & 27.52495 & 4.570144 & 3.935508 \\
Median & 0.676400 & 4.108234 & 26.54544 & 25.70316 & 3.213995 & 27.51495 & 4.540217 & 3.9307 \\
Maximum & 0.785600 & 4.272952 & 27.61279 & 26.76665 & 3.762011 & 28.34886 & 5.028475 & 3.966069 \\
Minimum & 0.577400 & 3.907516 & 25.33378 & 23.90173 & 2.560668 & 26.81439 & 4.12196 & 3.914012 \\
Std. Dev. & 0.056797 & 0.116431 & 0.750204 & 1.017140 & 0.369864 & .4485041 & .2800318 & 0.0141203 \\
Skewness & 0.253072 & -0.144094 & -0.050602 & -0.164186 & 0.043104 & .1305177 & .0686289 & .490193 \\
Kurtosis & 2.052889 & 1.765372 & 1.493102 & 1.482240 & 1.742354 & 1.916842 & 1.792779 & 2.154601 \\
Jarque-Bera & 1.393453 & 1.942224 & 2.756190 & 2.913802 & 1.920168 & 1.293353 & 1.49554 & 2.819190 \\
Probability & 0.498214 & 0.378662 & 0.252058 & 0.232957 & 0.382861 & 0.394414 & 0.45892 & 0.780058 \\
Sum & 19.66720 & 118.9984 & 768.7278 & 742.2970 & 92.65396 & 468.7078 & 8.2970 & 45.65396 \\
Sum Sq. Dev. & 0.090326 & 0.379571 & 15.75859 & 28.96805 & 3.830392 & 25.98459 & 3.96805 & 3.830392 \\
Observations & 29 & 29 & 29 & 29 & 29 & 26 & 26 & 26 \\
\hline
\end{tabular}

Source: author's own calculation

Table 3 reveals that the test statistic in both the models exceeds the I (1) critical value bound at all levels of significance. This provides a confirmation of presence of long run relationship between the green GDP and other independent variables. Upon confirmation of equilibrium relationship between the variables, long run as well as the short run responses of sustainability to independent variables especially trade openness is estimated. We expect a positive relationship between gross capital formation and green GDP and a negative relationship between the ratio of number of dependents to number of working people and green GDP. However, we make no hypothesis regarding the effect on green GDP with respect to trade openness. Table 4 presents the results of both the models through ARDL approach.

In Table 4, the upper panel shows the long run results and lower panel shows the short run results. As shown by the table, gross capital formation (LnGCF) has as expected positive and statistically significant coefficient. Gross capital formation positively impacts the growth rate of green GDP and therefore contributes to the sustainability conditions in India. The results indicate that with every incremental unit of capital formation, green GDP increases by 1.09 units. In model 2 LnGCF also shows similar

Table 3 F-Bounds Test

\begin{tabular}{lllll}
\hline & Test Statistic & Sig. & $I(0)$ & $I(1)$ \\
\hline Model 1 & & & & \\
-statistic & 4.948112 & $10 \%$ & 2.37 & 3.2 \\
K & 3 & $5 \%$ & 2.79 & 3.67 \\
& & $2.5 \%$ & 3.15 & 4.08 \\
& & $1 \%$ & 3.65 & 4.66 \\
Model 2 & 29.64 & & & \\
F-statistic & 3 & $10 \%$ & 2.37 & 3.2 \\
K & & $5 \%$ & 2.79 & 3.67 \\
& & $2.5 \%$ & 3.15 & 4.08 \\
& & $1 \%$ & 3.65 & 4.66 \\
\hline
\end{tabular}

Source; author's own calculation 
Table 4 ARDL results

\begin{tabular}{|c|c|c|c|c|c|}
\hline & \multicolumn{3}{|c|}{$\begin{array}{l}\text { MODEL } 1 \\
\text { Dependent variable GGDP }\end{array}$} & \multicolumn{2}{|c|}{$\begin{array}{l}\text { MODEL } 2 \\
\text { Dependent variable CSI }\end{array}$} \\
\hline & Variables & Coef. & $P$ value & Coef. & $P$ value \\
\hline \multirow[t]{3}{*}{ Long run coefficients } & LnADR & $.329(.68)$ & 0.63 & $.378(.20)$ & 0.142 \\
\hline & LnGCF & $1.091(.12)$ & 0.000 & $.81(.40)$ & 0.059 \\
\hline & LnTO & $-.605(.08)$ & 0.000 & $-.50(0.30)$ & 0.001 \\
\hline \multirow[t]{7}{*}{ Short run coefficients } & Cons. & $-7.81(6.46)$ & 0.244 & $2.00(1.54)$ & 0.210 \\
\hline & LnGCF & $1.27(.13)$ & 0.000 & $0.84(0.32)$ & 0.001 \\
\hline & LnADR & $.386(.77)$ & 0.625 & $0.39(1.06)$ & 0.971 \\
\hline & $\operatorname{LnGGDP}(-1)$ & $-.733(.12)$ & 0.001 & - & - \\
\hline & LnCSI & - & - & $0.78(0.98)$ & 0.031 \\
\hline & LnTO & $.71(.14)$ & 0.000 & $0.68(0.019)$ & 0.068 \\
\hline & Coint. Eq. & $-1.17(.12)$ & 0.000 & $-.84(.19)$ & 0.000 \\
\hline No of obs. & & 28 & & 28 & \\
\hline R-square & & .91 & & .56 & \\
\hline Adjusted R-square & & .87 & & .41 & \\
\hline Root MSE & & 0.045 & & 0.010 & \\
\hline Log likelihood & & 47.19 & & 92.80 & \\
\hline
\end{tabular}

Source: author's own calculation

Standard errors are given in parenthesis

LnTO stands for log of trade openness, LnGGDP is the log of green GDP; LnADR is log of average dependency ratio; LnGCF log of gross capital formation and CSI stands for composite sustainability indicator

effects on sustainability. However, the magnitude of its impact decreases from 1.09 to 0.81 units per incremental change in capital formation.

Log of trade openness (LnTO) has a significant negative coefficient in both the models. These results indicate that the impact of trade openness on sustainability is deteriorative. This can also be interpreted as, opening borders for cross country trade by India is leading it to borrow from future generations. There are number of channels through which trade openness can have negative repercussions on sustainability particularly in developing and third world countries. These include the migration of polluting industries, putting extra pressure on natural endowments and even by raising income inequality both within and among the countries. This finding supports the views of many environmentalists and dependency theorists, who claim that trade openness puts developing countries and poor people in great jeopardy. George and Krikpatrick (2004) stated that the reason for such negative correlation between trade openness and sustainability lies in the composition of foreign trade. Exports of primary and low value added products and import of high end goods reduces overall welfare. Genuine savings despite being a weak indicator of sustainability severs our purpose of analyzing impact of trade openness on sustainable development. In model 2 coefficient of trade openness mimics itself to that of model 1. This indicates the robustness of our results to any change in measurement of sustainability.

The log of age dependency ratio (LnADR) has shown surprising results contrary to our anticipation in both the models. The results show that as the number of dependents increase, green GDP also increases. This paradoxical finding may be due to one or multiple reasons for such relationship. Various factors including specification bias may also produce such contrary results. However, the residual tests as given in Table 5 
below indicates that no such statistical issue exists in the model. The R-square of 0.91 and Adjusted R-square of 0.87 are indicative of the explanation of changes in sustainable development by about $87 \%$. Also, the explanatory variables have significant collective impact on the regrassand (the model fit) as given by F-statistic. We believe that the presence of large unorganized labor sector in India may not be captured fully by the data. Further age dependency ratio is the composition of population but not economic dependency. Some children and elderly people are part of labor force and many working age people are outside its ambit. These two factors may be primarily responsible for such a positive relationship between age dependency and green GDP.

The lower panel of 4 reports the estimates of short run coefficients on impact of dynamic regressors on sustainability. In this regard, we employed Error correction model $(\mathrm{ECM})$. ECM shows the speed of adjustment of any deviation from the long run equilibrium. The coefficient on error correction term in both the models is found to be negative and statistically significant at all significance levels. It reflects that $117 \%^{*}$ and $84 \% *$ disequilibrium is corrected in the next period after a shock to the system. The significant coefficient ( 0.73 units) of GGDP at lag 1 indicates its mean reversion property after one period lag for a given shock in the system. In model 1 the coefficient of gross capital formation is statistically significant at $1 \%$ significance level with an estimate of 1.27 units. It reflects that one unit increase in gross fixed capital formation tend to increase green GDP by 1.27 units in the short run. Similar impact is gross capital formation is seen in model 2 also. Coefficient of age dependency ratio (ADR) is positive but insignificant in both the models which again is paradoxical as described above. The coefficients of trade openness in both the models are again both negative and significant. These results thereby means that trade openness reduces the sustainability by around 0.7 units in the short run. This depicts the consistency among the short run and long run effects of trade openness on sustainability in India.

While as, these results may appear to be influenced by independence, variance and covariance properties of the regression error term, it is customary to perform certain residual diagnostic testing. The results are shown in Table 5 below.

Table 5 reports the residual diagnostic tests of serial correlation and heteroskedasticity. Under the null hypothesis of serially uncorrelated residuals, the $p$-value associated with F- statistic is found to be 0.65 . Therefore, we fail to reject this null hypothesis and conclude that residuals are serially uncorrelated. Heteroskedasticity test under the null hypothesis of homoscedasticity of residuals, the p-value associated with F- statistic is found to be 0.73 . Therefore, we again fail to reject this null hypothesis and conclude that residuals are homoscedastic. In a similar vein, p-value associated with Ramsey RESET test also rejects presence of any omitted variable bias. Towards the end, the test statistic of Durbin-Watson test also validates the consistency of the model. Therefore we can conclude that the results of our study are robust and consistent. Further, the

Table 5 Residual Test

\begin{tabular}{lll}
\hline Test & Test statistic & $p$-value \\
\hline heteroskedasticity test: Breusch Pagan/ Cook-Weisberg & 0.20 & 0.65 \\
Breusch-Godfrey serial correlation LM test & 0.117 & 0.73 \\
Omitted variables Ramsey RESET test & 0.77 & 0.52 \\
Durbin-Watson test & 1.84 & \\
\hline
\end{tabular}


stability of the model is confirmed by the results of CUSUM and CUSUM squared (stability tests), presented in Fig. 1. This confirms our estimates to be reliable and consistent.

The graphical representation of stability test is shown in Fig. 1. The plot of cumulative sum of recursive residuals and squared residuals shown in in panel A and panel B shows that the parameters are stable over the sample period. Overall Table 5 and Fig. 1 indicates that the model has desirable statistical and theoretical properties and can be used for policy analysis.

\section{Gap between conventional GDP and green GDP}

As again, we started with the same procedure of detection of unit root. The results are reported in Table 1. The results of Augmented Dickey-Fuller test indicates the nonstationarity present at levels in all the variables. However, the stationarity was restored at first difference in all variables as indicated by their respective $p$-values given in bottom three rows of the 5th column of Table 1. On investigating whether trade openness affects the gap between conventional GDP and green GDP, we used both ARDL and OLS technique. However, before estimation of the regression coefficients descriptive statistics are presented. As reported in Table 2 the results indicate that the data is both normal as well as stable. The residual series however indicated presence of both heteroskedasticity and auto-correlation. To correct for the bias in standard errors due to heteroskedasticity and auto-correlation and to provide a more robust estimates for

Panel A: CUSUM Test

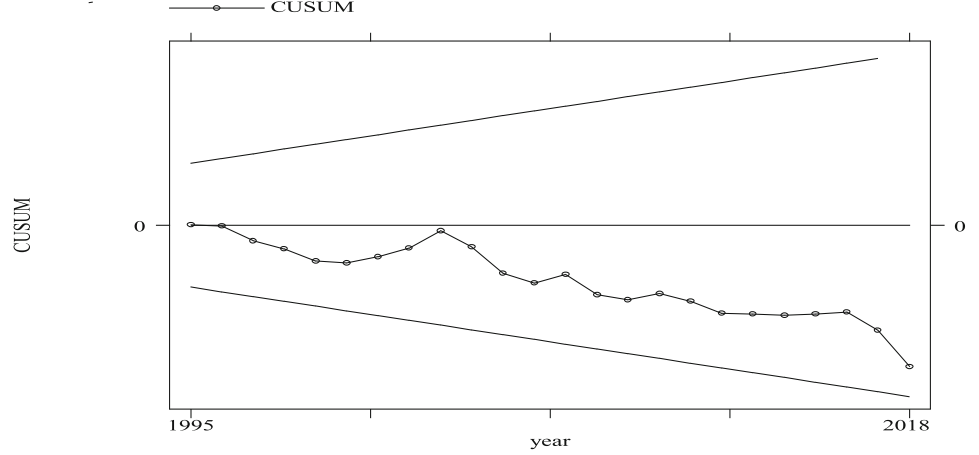

Panel B: CUSUM Square Test

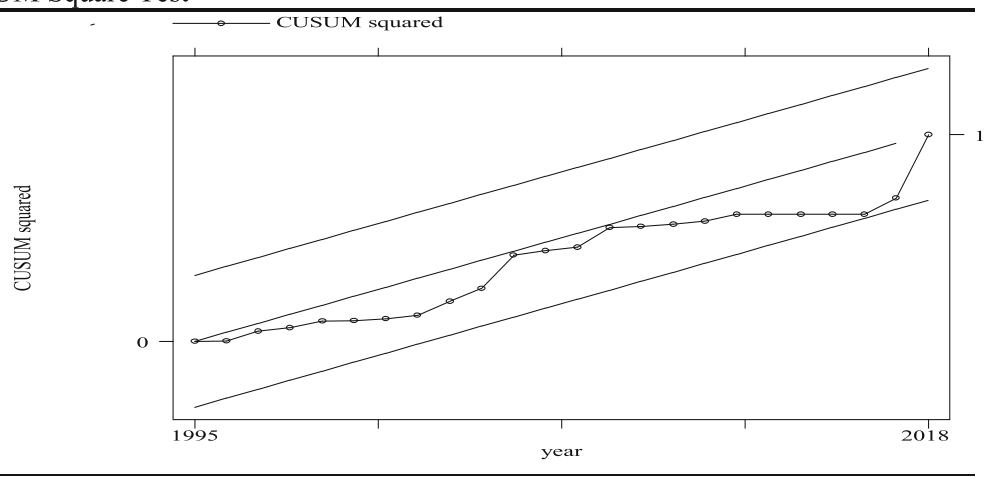

Fig. 1 Stability Tests 
inference regarding the significance of estimated coefficients, heteroskedasticity- and autocorrelation-consistent (HAC) standard errors were calculated. This procedure does not alter estimation, but changes only the estimates of the standard errors to ensure their consistency in presence of heteroskedasticity. All the variables have been taken in $\log$ form and estimates of regression coefficients are reports in Table 6.

As shown by the Table 6, in both the models, livestock production index (LnLPI) has as expected a positive influence on the gap. Taking all the factors constant, increase in livestock production widens the gap and reduce the sustainability conditions in India and vice versa. This may be through any of the multiple channels through which LPI contributes to environmental degradation. However, the insignificance of coefficient of LPI precludes from attributing any sort of such environmental degradation to livestock production in India. In the short run the negative sign of the coefficient of LnLPI indicates the positive effect on reduction of gap between conventional GDP and green GDP. However, the coefficient is again statistically insignificant.

Coefficient of LnTO indicates that trade openness is associated with more welfare costs than the gains generated by it. In the long run trade openness contributes positively and significantly in widening the difference between GDP and green GDP. In short run also trade openness shows similar effect. This finding in in line with our earlier results of green GDP which indicated that trade openness reduces the sustainability conditions in India. Our results lend support to the study of Max-Neef (1995) who also found similar results. However, contrary to our expectations, income inequality has a negative and significant coefficient in both the models. The negative sign shows that increase in income inequality reduces the gap between GDP and green GDP. This may be due to effect of marginal propensity to save. Higher income inequality leads to concentration of wealth in few hands thereby creation of economic pyramid. Those at the top of the pyramid have higher marginal propensity to save as compared to the bottom share. As we have relied upon adjusted net savings, increasing income of upper class

Table 6 GAP model Dependent variabl: GAP

\begin{tabular}{|c|c|c|c|c|c|}
\hline & \multirow[b]{2}{*}{ Variables } & \multicolumn{2}{|c|}{ Model 1 ARDL } & \multicolumn{2}{|l|}{ Model 2 OLS } \\
\hline & & $\overline{\text { Coeff. }}$ & $\overline{p \text {-value }}$ & $\overline{\text { Coeff. }}$ & $p$-value \\
\hline \multirow[t]{4}{*}{ Long run results } & LnGINI & $-1.63(.60)$ & 0.031 & $-2.00(0.72)$ & 0.011 \\
\hline & LnLPI & $0.38(.155)$ & 0.365 & $0.302(0.42)$ & 0.481 \\
\hline & LnTO & $.161(.114)$ & 0.07 & $.133(0.04)$ & 0.005 \\
\hline & Cons. & - & - & $0.05(0.01)$ & 0.004 \\
\hline \multirow[t]{5}{*}{ Short run results } & Cons & $24.18(6.32)$ & 0.001 & - & - \\
\hline & $\operatorname{LnGINI}$ & $-.62(1.71)$ & 0.722 & - & - \\
\hline & LnLPI & $-.37(1.01)$ & 0.720 & - & - \\
\hline & LnTO & $.027(0.11)$ & 0.019 & - & - \\
\hline & Coint. & $-1.24(0.32)$ & 0.001 & - & - \\
\hline $\begin{array}{l}\text { No of obs. } \\
\text { R-square } \\
\text { Adjusted R-square } \\
\text { Root MSE } \\
\text { Log likelihood } \\
\text { Durbin-Watson test }\end{array}$ & $\begin{array}{l}26 \\
0.339 \\
0.145 \\
0.010 \\
92.80 \\
2.11\end{array}$ & & \multicolumn{2}{|c|}{$\begin{array}{l}\text { R-squared } \\
\text { Adjusted R-squared } \\
\text { S.E. of regression } \\
\text { Log likelihood } \\
\text { F-statistic } \\
\text { Durbin-Watson stat } \\
\text { Prob. (F-statistic) } \\
\text { Wald F-statistic } \\
\text { Prob.(Wald F-statistic) }\end{array}$} & $\begin{array}{l}0.199920 \\
0.085623 \\
0.056158 \\
38.69570 \\
1.749128 \\
2.588713 \\
0.187740 \\
3.991272 \\
0.001415\end{array}$ \\
\hline
\end{tabular}


with high marginal propensity to save positively influence the savings which in-turn reduces the gap. The variation explained $\left(R^{2}\right)$ by the model is low for the reason that the vast set of other factors have strong influence on sustainable development. Those variables have not been included for the reason of collinearity as our dependent variable is adjusted for almost all such variables. Fig. 2 shows the results of CUSUM and CUSUM square test thereby stability of the model. The blue line located within the two red lines indicated that our model is stable.

The plot of cumulative sum of recursive residuals and squared residuals shown in in panel A and panel B shows that the parameters are stable over the sample period. Overall Fig. 1 indicates that the model has desirable statistical and theoretical properties and can be used for policy analysis.

\section{Conclusion and policy implications}

Our estimation supports the opinion of environmentalists. We examined the implications of trade openness on one of the World Bank's composite weak sustainability measure known as genuine savings (GS). The results show the opposite view of the previous studies. We found that cross-border trade reduces green GDP significantly and increases the gap between GDP and green-GDP in india. This refutes the fundamental principle of trade theory, which states that free trade maximizes productivity in the use of world resources, including natural capital and the environment. These findings are consistent with environmentalists and social commentators who argue that trade openness and economic activity is associated with higher welfare costs. Additionally, our

Panel A: CUSUM Test

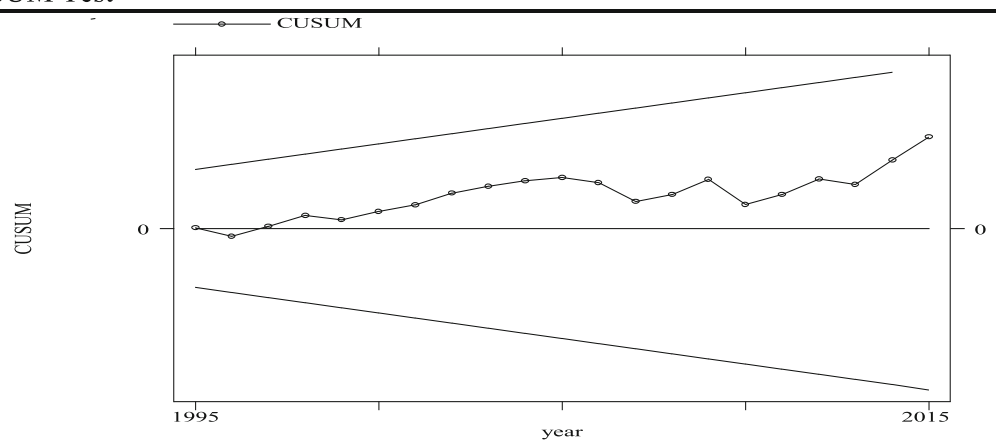

Panel B: CUSUM Square Test

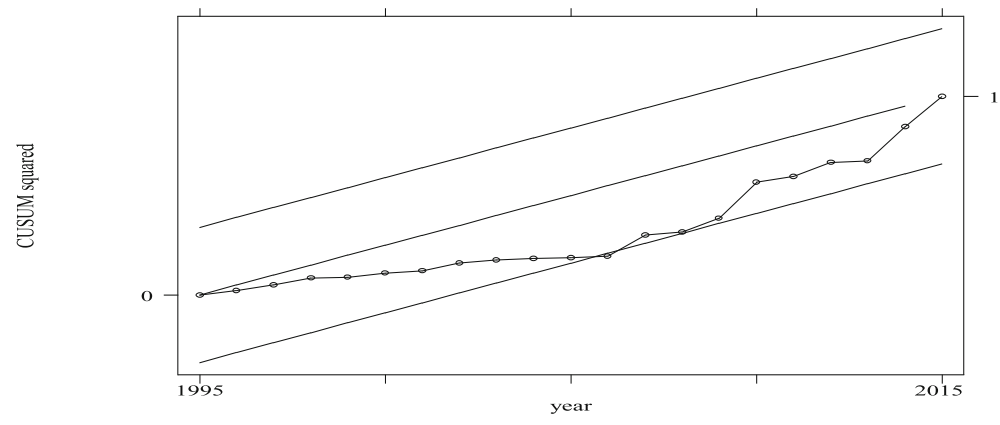

Fig. 2 Stability Tests of GAP Model 
results hold for weak sustainability meaning thereby, it will also hold for strong sustainability.

However, few things should be borne in mind. The foregoing analysis suggests that green GDP is a useful tool for examining the influence of other factors on sustainable development. Here we used the production function framework incorporated with green GDP. As Talberth and Bohara (2006) puts it that there is no global consensus regarding alternative measures of green GDP. The methodological variation remains the bone of contention. Our measure of green GDP is also a crude measure of sustainable development. The weak sustainability paradigm pitches for resources to be atleast nondeclining for future generations. This approach invariable balances one against the other. Keeping in view the earth's resilience, depleted natural capital, gravely damaged environment a broken social contract may not be compensated. Further, it is assumed that trade openness is exogenous to avoid the complications of endogeneity and causality. For these reasons, the results of this study should be taken with a grain of salt. Despite these limitations, it provides a gainful insights to assess the impact of trade openness on sustainability in India. We believe that the study is useful in Indian context where paucity of comprehensive empirical study covering all the three components of sustainability is found. This study sets the platform to assess impact of trade policy in a broader framework of sustainable development.

Acknowledgements

Not applicable.

\section{Authors' contributions}

MAS and MAM did the theoretical aspect and performed the econometric and statistical analysis. RZM did the sequence alignment, design draft of the manuscript. Both the authors approved the final draft of the manuscript once thoroughly checked. All authors read and approved the final manuscript.

Funding

The authors have received no specific funding for this work.

Availability of data and materials

The data is readily available with the authors and can be provided upon request.

Ethics approval and consent to participate

The paper contains no malicious content.

Competing interests

The authors declare that they have no competing interests.

\section{Author details}

${ }^{1}$ Department of Commerce, Aligarh Muslim University, Aligarh, India. ${ }^{2}$ Department of West Asian Studies, Aligarh Muslim University, Aligarh, India.

Received: 18 August 2019 Accepted: 11 December 2019

Published online: 03 January 2020

\section{References}

Amin S (1990) Maldevelopment: anatomy of a global failure. Zed, London

Balassa B (1986) Policy responses to exogenous shocks in developing countries. Am Econ Rev 5:75-78

Bellmann C, Latif AA, Hepburn J (2011) Promoting sustainable development in global trade and multilateral negotiations. Int J Dev Policy 2:163-193

Bornschier V, Chase-Dunn C (1985) Transnational corporations and underdevelopment. Praege, New York

Brecher J, Costello T (1994) Global Village or global pillage, economic reconstruction from the bottom up. South End Press, Boston

Coe D.T., E. Helpman (1995). International R\&D spillovers (working paper, no. 4444). Retrieved from National Bureau of Economic Research website: http://www.nber.org/papers/w4444

Copeland BR, Taylor MS (1994) North-south trade and the environment. Q J Econ 109(3):755-787

Costanza, R., Hart, M., Posner, S., Talberth J. (2009). Beyond GDP: the need for new measures of Progress. The pardee papers

Dar JA, Asif M (2018) Does financial development improve environmental quality in Turkey? An application of endogenous structural breaks based cointegration approach. Manag Environ Qual: Int J 29(2):368-384 
Desai RM, Rudra N (2018) Trade, poverty, and social protection in developing countries. Eur J Pol Econ xxx:1-11

Denise H. Froning, (2000). The Benefits of Free Trade: A Guide for Policymakers. Heritage Foundation Backgrounder, No. 1391

Dowrick S (1994) Openness and growth: international integration of the Australian economy. Reserve Bank of Aust Sydney 8(21):9-41

Dollar D (1992) Outward-oriented developing economies really do grow more rapidly: evidence from 95 LDCs, $1976-1985$. Economic development and cultural change 40(3):523-544

Engle RF, Granger CW (1987) Co-integration and error correction: representation, estimation, and testing. Econometrica: journal of the Econometric Society 251-276

George C, Krikpatrick C (2004) Trade and development: assessing the impact of trade liberalization on sustainable development. J World Trade 38(3):441-469

Johansen S (1988) Statistical analysis of cointegration vectors. Journal of economic dynamics and control 12(2-3):231-254

Johansen S (1991) Estimation and hypothesis testing of cointegration vectors in Gaussian vector autoregressive models. Econometrica: journal of the Econometric Society 1551-1580

Johansen S, Juselius K (1990) Maximum likelihood estimation and inference on cointegration-with applications to the demand for money. Oxford Bulletin of Economics and statistics 52(2):169-210

Kaldor N (1964) International trade and economic development. J Mod Afr Stud 2(4):491-511

Kraay A (1999) Exports and economic performance: evidence from a panel of Chinese enterprises. Revue d' Economique Dev 2:183-207

Krishna P, Mitra D (1998) Trade liberalization, market discipline and productivity growth: new evidence from India. J Dev Econ 56(2):447-462

Krueger A (1998) Why trade liberalisation is good for growth. The economic journal 108(450):1513-1522

Lawn PA (2003) A theoretical foundation to support the Index of Sustainable Economic Welfare (ISEW), Genuine Progress Indicator (GPI), and other related indexes. Ecological Economics 44(1):105-118

Lee JW (1995) Capital goods import and long-run growth. Dev Econ 48(1):91-110

Lucas RE (1988) On the mechanics of economic development. J Monetary Econ 22(1):3-42

Max-Neef M (1995) Economic growth and quality of life: a threshold hypothesis. Ecol Econ 15:115-118

Mountford A (1999) Trade dynamics and endogenous growth: an overlapping generations analysis. Econ New Series 66(262): 209-224

Pesaran MH, Shin Y, Smith RP (1999) Pooled mean group estimation of dynamic heterogeneous panels. Journal of the American Statistical Association 94(446):621-634

Pesaran MH, Shin Y, Smith RJ (2001) Bounds testing approaches to the analysis of level relationships. Journal of applied econometrics 16(3):289-326

Rodrigues, F., Rodrik, R. (1999). Trade policy and economic growth: a Skeptic's guide to the cross-National Evidence (working paper no: 7081), Retrieved from National Bureau of Economic Research website: http://www.nber.org/papers/w7081

Romer PM (1986) Increasing returns and long-run growth. J Polit Econ 94(5):1002-1037

Ropke I (1994) Trade, development and sustainability: a critical assessment of the "free trade dogma". Ecol Econ 9(1):13-22

Rosenberg RL (1994) Trade and the environment: economic development versus sustainable development. J Interam Stud World Affairs 36(3):129-156

Rudra N (2002) Globalization and the decline of the welfare state in less developed countries. Int Organ 56(2):411-445

Rudra N (2008) Globalization and the race to the bottom in developing countries: who really gets hurt? Cambridge University Press, New York

Stiglitz JE, Sen A, Fitoussi JP (2010) Mismeasuring our lives: why GDP Doesn't add up. The new press, New York

Stokey NL (1988) Learning by doing and the introduction of new goods. J Polit Econ 96(44):701-717

Talberth J, Bohara AK (2006) Economic openness and green GDP. Ecol Econ 58:743-758

Tokos H, Pintaric ZN, Krajic D (2012) An integrated sustainability performance assessment and benchmarking of breweries. Clean Techn Environ Policy 14(2):173-193

United Nations 1962 World Economic Survey 1962, New York: United Nations Publication

Weiss EB (1992) Environment and trade as partners in sustainable development: a commentary. Am J Int Law 86:728-735

Were M (2015) Differential effects of trade on economic growth and investment: a cross country empirical investigation. J Afr Trade 2(1-2):71-85

\section{Publisher's Note}

Springer Nature remains neutral with regard to jurisdictional claims in published maps and institutional affiliations.

\section{Submit your manuscript to a SpringerOpen ${ }^{0}$ journal and benefit from:}

- Convenient online submission

- Rigorous peer review

- Open access: articles freely available online

- High visibility within the field

- Retaining the copyright to your article

Submit your next manuscript at $\boldsymbol{\nabla}$ springeropen.com 